\title{
Detection of Coconut cadang-cadang viroid sequences in oil and coconut palm by ribonuclease protection assay
}

\begin{abstract}
A ribonuclease protection assay (RPA) has been developed for detecting Coconut cadangcadang viroid (CCCVd) sequences. An RNA probe complementary to full-length CCCVd246 was used, terminating at nucleotide 65 in the upper conserved region, and linked to a nonviroid 5' sequence, which acted as an internal control for ribonuclease activity. Extracts from CCCVd-infected coconut (Cocos nucifera) and African oil (Elaeis guineensis) palms protected three major fragments of approximately 250, 125 and $50 \mathrm{nt}$ and a variable number of minor fragments. Extracts of healthy coconut palms, Potato spindle tuber viroid-infected tomato and transfer RNA did not protect the probe. The approximately $250 \mathrm{nt}$ fragment is predicted to indicate the presence of monomers and dimers of circular CCCVd246, linear $\mathrm{CCCVd} 246$ with the same termini as the probe and point mutants of these forms. The origin of smaller protected fragments is discussed. RPA-detected CCCVd sequences in 13 of 18 oil palms surveyed in a commercial plantation in Malaysia. Signal intensity varied between the positive oil palms and was generally lower than in coconut palms infected with CCCVd. An infection phenotype was implied but not confirmed by the observation that in a group of 10 oil palms with orange leaf spotting, 9 contained CCCVd, whereas in a group of 8 palms without orange spotting, the viroid was detected in 4. Of four coconut palms in Sri Lanka shown by dot-blot assay to contain CCCVd-related RNA, one was shown by RPA to be positive for the CCCVd246 sequence. RPA is therefore a robust and sensitive test for CCCVd sequences, and our results show that sequences closely related to CCCVd246 are not confined to the Philippines.
\end{abstract}

Keyword: bioassay, biological survey, detection method, enzyme activity, monocotyledon, plantation, Cocadviroid Coconut cadang-cadang viroid, Cocos nucifera, Elaeis, Elaeis guineensis, Lycopersicon esculentum, Potato spindle tuber viroid, Solanum tuberosum, Viroids 